\title{
The Influence of Organizational Justice on Employees Compulsory Citizenship Behavior: The Mediation Effect of Psychological Security
}

\author{
Zhen Zeng, Maolin Ye \\ School of Management, Jinan University, Guangzhou, China \\ Email: zengzhen101@foxmail.com
}

Received 29 January 2016; accepted 26 February 2016; published 29 February 2016

Copyright (C) 2016 by authors and Scientific Research Publishing Inc.

This work is licensed under the Creative Commons Attribution International License (CC BY). http://creativecommons.org/licenses/by/4.0/

\section{(c) O) Open Access}

\begin{abstract}
In this paper, we explore the influence mechanism of compulsory citizenship behavior. The article explores the relationship between organizational justice and compulsory citizenship behavior in the view of social exchange theory. With regression analysis of 260 samples, we find that organizational justice has a significant effect on compulsory citizenship behavior. Meanwhile, psychological security plays a part in mediating the effect.
\end{abstract}

\section{Keywords}

Organizational Justice, Compulsory Citizenship Behavior, Psychological Security

\section{Introduction}

Organizational citizenship behavior (OCB), as a spontaneous behavior of employees, is not forced by working manual nor explicitly pointed out in the normal compensation system. But it can improve the effectiveness of the organization operation [1]. Lots of studies have shown that OCB plays a constructive role in employee job performance and organizational efficiency [2], so managers tend to expect employees to show more OCB in the work [3]. However, the pressure from managers is likely to lead to employees' involuntary OCB [4]. For example, under abusive supervision, employees will be forced to implement OCB in order to improve the organizational efficiency. In this case, the original voluntary and spontaneous behavior is evolved into a false and passive OCB [5] [6]. Vigoda [7] defines this false and passive OCB as Compulsory citizenship behavior (CCB) in the redefinition of OCB boundary, that is involuntary OCB showed by the staff under the pressure of subject, object 
and organizational environment. It will not improve the organizational performance. Instead, it will bring a series of adverse effects on organization [7].

Most of existing research thought the influence factors of CCB and OCB are the same, they just work or manifest in a different way [8]. In recent years, scholars have been more and more interested in issues of fairness in the field of industrial and organizational psychology [9]. Studies have shown that employees' feeling about organizational justice significantly affect their motivation to perform OCB, and with the spontaneity of OCB [10]. When employees are treated unfairly, their citizenship behavior is likely to be involuntary. Therefore, Vigoda [7] points out that organizational justice may have a significant effect on CCB, but it has not been empirically tested.

Zhao [10] points out that, in general, negative behaviors tend to have a greater significance compared with the positive behaviors. In this respect, the study on CCB may be more meaningful than on OCB. Although this concept is put forward in the western cultural background, some scholars point out that employees may show more CCB in the Chinese cultural context because they are more likely to promote to leaders' demand with cultural heritage of complying with the leadership [11]. Therefore, the study on CCB in China has more realistic significance. Past studies on CCB mainly focus on the result variables [12], so there are few studies focused on influence factors. In view of this, we discuss the influence and function mechanism of organizational justice on CCB in China. It will help us to understand the causes of CCB and provide direction for the prevention and control of CCB.

\section{Organizational Justice and CCB}

Organizational justice refers to the judgment, perception and feelings of organizational justice from employees. It is divided into distributive justice, procedural justice, interpersonal justice (leadership justice) and information justice. From the perspective of social exchange theory, in the process of the exchange of individuals and organizations, employees perceive whether they are treated fairly or not in organization distribution, leadership, information, procedures and other aspects. And the employee's OCB is a return willing act based on social exchange [13]. Employees who were treated fairly will trust and be satisfied with the company and they will perform more OCB in return [14]. In contrast, employees who were treated unfairly will generate resentment and anger [15] and reduce the trust and identity of the company [16]. In this case, the staff may well refuse to do something beyond duties which is good for organization. But if he or she refuses to perform the desired behavior, he or she is likely to lose the chance of promotion and even the job [17]. In order not to harm more personal interests, employees may have to join in the fun on occasion, so as to show the CCB. On the other hand, it was proved by a number of studies that organizational justice has great effect on OCB [14]. In view of the same influence factors of the two, we can speculate that organizational justice has a significant effect on CCB.

Hypothesis 1: Organizational justice has a significant effect on CCB.

\section{The Mediating Role of Security}

Studies have pointed out that the cognitive and emotional state of employees can be used as bridge between organizational environment, leadership behavior and their result variables [18] [19]. Psychological security refers to a kind of subjective psychological feeling that members dare to express their own intentions without threat to their position in the organization and future career [20]. It reflects the employees' perception of working environment and atmosphere and is closely related to whether they are worried about their interests in the workplace [21]. Organizational justice coterminous with the personal interests of the employees, so, as one of the important forecast source of staff behavior [3], psychological security may act as mediator between organizational justice and CCB.

Social information processing theory believes that social environment the man lives in provides a variety of social information which will affect his attitude and adjust his behavior. So people's attitudes and behavior is not only depended on their own needs and goals, but also on the surrounding environment. Fair organization environment means reasonable resource allocation (distributive justice), open and transparent assessment selection mechanism (procedural justice), fair treatment from the leader (leadership justice; information justice) etc., and it can build a good interpersonal relationship and enterprise atmosphere [22]. Employees get a higher psychological security in a open and tolerant environment [20] because they needn't to worry about the negative impact on their own interests even if they do not perform what they are expected to do. As a result, it reduces the gener- 
ation of CCB. While the organization lacks of fair distribution system (distributive justice), the rights of account and participation (procedural justice) and fair treatment from the leadership (leadership justice; information justice), it will aggravate the sense of powerlessness as the staff think that their interests cannot be guaranteed. At this time, CCB may act as a political social tool [23] to deal with adverse environment and prove his value by creating a good image through working harder [24]. So psychological security may act as a mediator of the relationship between organization justice and CCB.

Hypothesis 2: psychological security acts as a mediator of the relationship between organization justice and CCB.

\section{Method of Data Collection}

We used The Questionnaire Star to collect the data. 260 employees from different enterprise participated in the study (male $=165$, female $=95$, average). The sample cottecting via internet met the demand of Convenience (non-probability) sampling technique.

A 22-item scale developed by Ya Liu, Li Rong and Ye Li [25] was used to measure organizational justice. The scale includes four dimensions: distributive justice, procedural justice, leadership justice and information justice. 3 items of the original questionnaire were deleted according to the result of confirmatory factor analysis. A 3-item scale developed by May was used to measure employees' psychological security. The scale includes just one dimension. The scale's alpha reliability in this study is 0.801 . A 5-item scale developed by Vigoda [17] was used to measure CCB. The scale includes just one dimension. 1 item of the original questionnaire was deleted according to the result of confirmatory factor analysis. The scale's alpha reliability in this study is 0.832 .

\section{Analyses and Results}

\subsection{Reliability Analysis}

We used confirmatory factor analysis to estimate composite reliability while used Delta to estimate its standard error. So we cannot only get the point estimates of composite reliability but also the error range of the estimation, thus providing a more accurate assessment of the quality of the test. The results showed that composite reliability of all scales is above 0.8 . And the low limit of $95 \%$ confidence interval is below 0.75 (Table 1 ).

\subsection{Mediation Test}

We used spss 13.0 and liserl to process the data. The means, standard deviation and correlation coefficients of the study variables are shown in Table 1 . The correlation coefficients indicated that organizational justice and its all dimesions were correlated with CCB. This pattern of results partially satisfied the first condition of mediation (Table 2).

To evaluate the other condition for mediation, we use latent variable modeling to analyze the relationship among variables. We built a 4 single-factor CFA model corresponding the 4 dimensions of organizational justice. Then we composited the scores of each dimension according to the means. As a result, we got 4 significant indicators of organizational justice including leadership justice, distributive justice, information justice and procedural justice.

Table 1. Composite reliability and confidence interval of each scale.

\begin{tabular}{cccc}
\hline Scale & Number of items & Composite reliability & 95\% Confidence interval \\
\hline Leadership justice & 5 & 0.908 & {$[0.890,0.925]$} \\
Distributive justice & 4 & 0.882 & {$[0.858,0905]$} \\
Information justice & 4 & 0.911 & {$[0.893,0.928]$} \\
Procedural justice & 6 & 0.878 & {$[0.855,0.901]$} \\
Psychological security & 3 & 0.801 & {$[0.759,0.843]$} \\
CCB & 5 & 0.832 & {$[0.799,0.865]$} \\
\hline
\end{tabular}


Table 2. Descriptive statistics and correlations among study variables $(\mathrm{n}=260)$.

\begin{tabular}{|c|c|c|c|c|c|c|c|c|}
\hline Variable & Means & SD & 1 & 2 & 3 & 4 & 5 & 6 \\
\hline 1. Leadership justice & 4.34 & 0.862 & & & & & & \\
\hline 2. Distributive justice & 3.86 & 0.968 & $0.36 * *$ & & & & & \\
\hline 3. Information justice & 3.84 & 0.995 & $0.46^{* *}$ & $0.69 * *$ & & & & \\
\hline 4. Procedural justice & 3.69 & 0.930 & $0.39 * *$ & $0.59 * *$ & $0.65^{* *}$ & & & \\
\hline 5. Organizational justice & 3.92 & 0.763 & $0.65 * *$ & $0.81 * *$ & $0.86^{* *}$ & $0.80 * *$ & & \\
\hline 6. Psychological security & 3.96 & 0.905 & $0.23 * *$ & $0.26 * *$ & $0.33 * *$ & $0.32 * *$ & $0.38^{* *}$ & \\
\hline 7.CCB & 3.88 & 0.912 & $-0.24^{* *}$ & $-0.26 * *$ & $-0.28 * *$ & $-0.25^{* *}$ & $-0.34 * *$ & $-0.39 * *$ \\
\hline
\end{tabular}

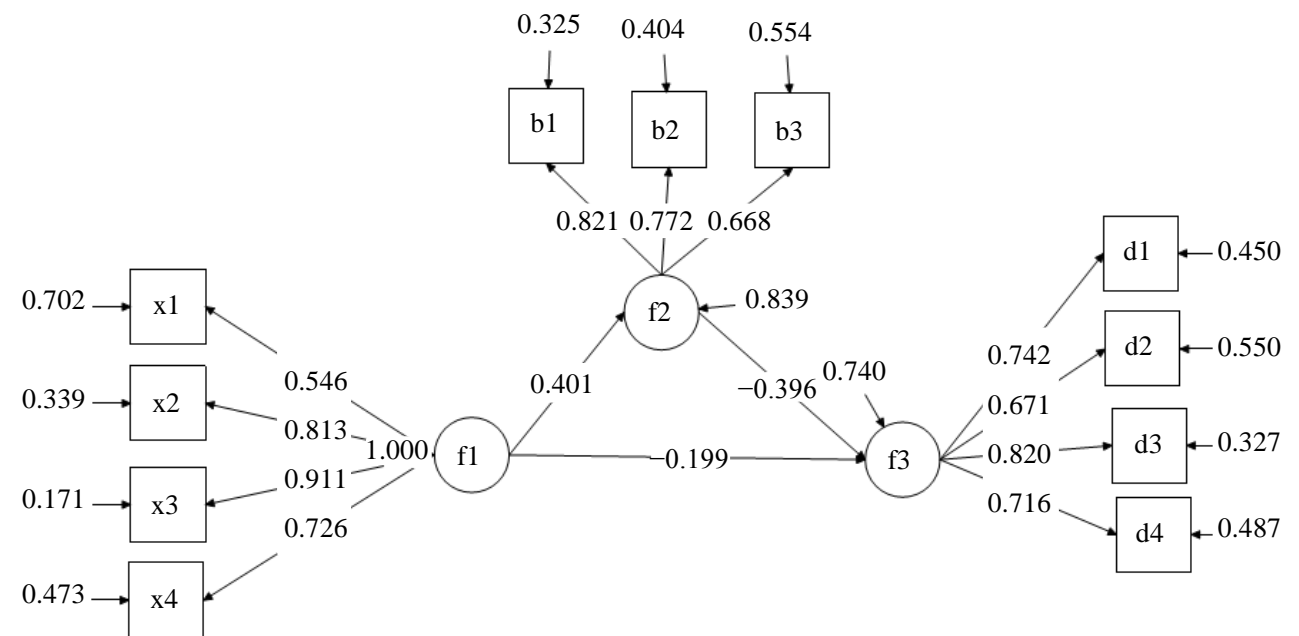

Figure 1. The Mediation model of psychological security. $\mathrm{f} 1$ = organizational justice; $\mathrm{f} 2$ = psychological security; $\mathrm{f}$ = CCB; $\mathrm{x} 1$ = leadership justice; $\mathrm{x} 2$ = distributive justice; $\mathrm{x} 3$ = information justice; $\mathrm{x} 4$ = procedural justice.

At last, this study established mediation model of psychological security. Path coefficient of the mediation model was shown in Figure 1. The model fitting index met the recommended standard $(\chi 2=63.574, \mathrm{df}=41$, RMSEA $=0.046$, SRMR $=0.033$, CFI $=0.98$, NNFI $=0.974)$. The direct effects and total effects of organizational justice on CCB are -0.199 and -0.358 respectively. So the intermediary effects are -0.159 . Meanwhile, the result of Bootstrap showed that the $95 \%$ confidence interval of intermediary effects was $(-0.225,-0.063)$ excluding 0 . The percentage of intermediary effects in total effects is $-0.159 /(-0.358)=44.4 \%$.

So we find that organizational justice has a significant effect on compulsory citizenship behavior; meanwhile, psychological security plays a part in mediating the effect (Figure 1).

\section{Discussion}

It has been widely recognized that OCB has promoting effect on team work and organizational operation [2]. However, CCB, as the "dark side" of OCB, has a negative impact on organization. Commercial competition of modern society has been more and fiercer. Modern organization has to maximize its efficiency by all means. Organizations with high citizenship behavior often have the whip hand, thus managers may ignore the feeling of employees and force them to perform CCB [7]. This study explores the relationship between organizational justice and CCB as well as the mediating effect of psychological security. The results show that organizational justice plays an important role in shaping the psychological security of employees and CCB and organizational justice influences CCB through psychological security. The results of the study have the following theoretical and practical significance.

First of all, the past study focuses on the positive perspective of OCB, but this study focuses on the "dark side" of OCB, that is, CCB. Employees with high OCB are not always the "good soldier" and they are probably the 
"good actor" of the organization. This will help us to deepen the understanding of OCB. Secondly, this study helps managers to recognize the two-sword effects of OCB and learn to arouse the voluntary citizenship behavior while avoid compulsory citizenship behavior. Finally, the empirical research verifies the existence of CCB in the Chinese context and explores the antecedent variables of CCB. By confirming the impact of organizational justice on CCB, it can provide theoretical guidance of further control and reduction of CCB. Social exchange theory thinks that when employees receive good treatment, they will do something good for the company to pay back, like, take the initiative to help colleagues. So enterprise managers should care more about the subordinates and establish a good working environment to create an atmosphere of "civil society", so as to stimulate the enthusiasm of employees to implement the civil behavior. Beside, in order to reduce CCB, enterprises should enhance organizational justice through changing their concepts, improving the performance appraisal system, establishing scientific position management, and so on. Leadership justice has a special meaning in Chinese cultural background. To reduce CCB, it is particularly important for managers to pay attention to the communication with employees and leader-member relations.

The dark side of OCB has special significance; future research may continue exploring the mechanism of CCB. Though we have learned that organizational justice plays an important role in shaping the CCB of employees, the influence factors of CCB still need further study.

\section{References}

[1] Organ, D.W. (1988) Organizational Citizenship Behavior: The Good Soldier Syndrome. Lexington Books/DC Heath and Com.

[2] Podsakoff, N.P., Podsakoff, P.M., MacKenzie, S.B., Maynes, T.D. and Spoelma, T.M. (2014) Consequences of UnitLevel Organizational Citizenship Behaviors: A Review and Recommendations for Future Research. Journal of Organizational Behavior, 35, S87-S119. http://dx.doi.org/10.1002/job.1911

[3] Gregory, B.T., Osmonbekov, T. and Gregory, S.T. (2009) Abusive Supervision and Organizational Citizenship Behaviors: An Examination of Potential Boundary Conditions. Unpublished Manuscript, The WA Franke College of Business, Northeast Arizona University, Flagstaff, Arizona.

[4] Bolino, M.C., Turnley, W.H., Gilstrap, J.B. and Suazo, M.M. (2010) Citizenship under Pressure: What's a “Good Soldier” to Do? Journal of Organizational Behavior, 31, 835-855. http://dx.doi.org/10.1002/job.635

[5] Tepper, B.J., Duffy, M.K., Hoobler, J. and Ensley, M.D. (2004) Moderators of the Relationships between Coworkers' Organizational Citizenship Behavior and Fellow Employees’ Attitudes. Journal of Applied Psychology, 89, 455. http://dx.doi.org/10.1037/0021-9010.89.3.455

[6] Zellars, K.L., Tepper, B.J. and Duffy, M.K. (2002) Abusive Supervision and Subordinates' Organizational Citizenship Behavior. Journal of Applied Psychology, 87, 1068. http://dx.doi.org/10.1037/0021-9010.87.6.1068

[7] Vigoda-Gadot, E.R.A.N. (2006) Compulsory Citizenship Behavior: Theorizing Some Dark Sides of the Good Soldier Syndrome in Organizations. Journal for the Theory of Social Behaviour, 36, 77-93. http://dx.doi.org/10.1111/j.1468-5914.2006.00297.x

[8] Peng, Z. and Zhao, H. (2010) Review on Compulsory Citizenship Behavior. Foreign Economics \& Management, 6, 46-51.

[9] Greenberg, J. and Colquitt, J.A. (Eds.) (2013) Handbook of Organizational Justice. Psychology Press.

[10] Zhao, H. and Peng, Z. (2012) The Influence Factors of Compulsory Citizenship Behavior in the Grounded Theory Approach. Management Review, 24, 132-139.

[11] Farh, J.L., Zhong, C.B. and Organ, D.W. (2004) Organizational Citizenship Behavior in the People’s Republic of China. Organization Science, 15, 241-253. http://dx.doi.org/10.1287/orsc.1030.0051

[12] Bolino, M.C., Turnley, W.H. and Niehoff, B.P. (2004) The Other Side of the Story: Reexamining Prevailing Assumptions about Organizational Citizenship Behavior. Human Resource Management Review, 14, 229-246. http://dx.doi.org/10.1016/j.hrmr.2004.05.004

[13] Xu, C.J. and Shi, K. (2004) Controversy and Thinking of Organizational Citizenship Behavior. Management Review, 16, 45-50.

[14] Brebels, L., De Cremer, D. and Van Dijke, M. (2014) Using Self-Definition to Predict the Influence of Procedural Justice on Organizational-, Interpersonal-, and Job/Task-Oriented Citizenship Behavior. Journal of Management, 40, 731-763. http://dx.doi.org/10.1177/0149206311410605

[15] Blau, P.M. (1964) Justice in Social Exchange. Sociological Inquiry, 34, 193-206.

http://dx.doi.org/10.1111/j.1475-682X.1964.tb00583.x 
[16] Loi, R., Hang-Yue, N. and Foley, S. (2006) Linking Employees’ Justice Perceptions to Organizational Commitment and Intention to Leave: The Mediating Role of Perceived Organizational Support. Journal of Occupational and Organizational Psychology, 79, 101-120. http://dx.doi.org/10.1348/096317905X39657

[17] Vigoda-Gadot, E. (2007) Redrawing the Boundaries of OCB? An Empirical Examination of Compulsory Extra-Role Behavior in the Workplace. Journal of Business and Psychology, 21, 377-405. http://dx.doi.org/10.1007/s10869-006-9034-5

[18] Aryee, S., Chen, Z.X., Sun, L.Y. and Debrah, Y.A. (2007) Antecedents and Outcomes of Abusive Supervision: Test of a Trickle-Down Model. Journal of Applied Psychology, 92, 191-201. http://dx.doi.org/10.1037/0021-9010.92.1.191

[19] Avolio, B.J., Zhu, W., Koh, W. and Bhatia, P. (2004) Transformational Leadership and Organizational Commitment: Mediating Role of Psychological Empowerment and Moderating Role of Structural Distance. Journal of Organizational Behavior, 25, 951-968. http://dx.doi.org/10.1002/job.283

[20] Kahn, W.A. (1990) Psychological Conditions of Personal Engagement and Disengagement at Work. Academy of Management Journal, 33, 692-724. http://dx.doi.org/10.2307/256287

[21] Walumbwa, F.O. and Schaubroeck, J. (2009) Leader Personality Traits and Employee Voice Behavior: Mediating Roles of Ethical Leadership and Work Group Psychological Safety. Journal of Applied Psychology, 94, 1275-1286. http://dx.doi.org/10.1037/a0015848

[22] Colquitt, J.A., Conlon, D.E., Wesson, M.J., Porter, C.O. and Ng, K.Y. (2001) Justice at the Millennium: A Meta-Analytic Review of 25 Years of Organizational Justice Research. Journal of Applied Psychology, 86, 425-445. http://dx.doi.org/10.1037/0021-9010.86.3.425

[23] Le, J.-A., Peng, Z.-L. and Gao, Y. (2013) Research on the Mechanism of Workplace Ostracism and Compulsory Citizenship Behavior. East China Economic Management, No. 2, 106-111.

[24] Brockner, J., Grover, S.L. and Blonder, M.D. (1988) Predictors of Survivors’ Job Involvement Following Layoffs: A Field Study. Journal of Applied Psychology, 73, 436-442. http://dx.doi.org/10.1037/0021-9010.73.3.436

[25] Li, Y., Long, L.R. and Liu, Y. (2003) The Development of Organizational Justice. Advances in Psychological Science, 11, 78-84. 